\title{
ROMAN AMPHORA TRADE ACROSS THE STRAITS OF GIBRALTAR: AN ANCIENT 'ANTI-ECONOMIC PRACTICE'?
}

\begin{abstract}
Summary. Olive oil and fish products from the south of Hispania and North Africa played an important role in the Roman economy. The authors call attention to the asymmetrical distribution of archaeological data available on this subject, in particular the location of amphora kilns, and try to give an explanation, based on the evolution of European archaeology in the twentieth century.
\end{abstract}

This paper focuses on Roman maritime trade in the 'Circle of the Straits', ${ }^{1}$ the area between the provinces of Baetica (Andalucia) and Mauretania Tingitana (Morocco), where '. . . both the Baetis and the Anas empty, and the limits of Maurusia, the Atlantic Ocean breaks in and thus forms the strait at the Pillars, and by this strait the interior sea connects with the exterior sea' (Strabo III 1, 7: trans. H.L. Jones, Loeb edition 1923). It will not judge or discuss the question of rationality or irrationality in the ancient economy for which the reader is referred to the relevant recent bibliography (Rathbone 1991; Andreau and Maucourant 1999; Lo Cascio and Rathbone 2000; Scheidel and von Reden 2002; Christensen 2003; Andreau 2005; Carrié 2005; Lautman 2005; Minaud 2005; Rathbone 2005; Tchernia 2005).

The historical and economic context is well known. From the beginning of the Roman occupation of the Iberian Peninsula, the fertile valley of the Baetis - the later Guadalquivir played a key role in the Romanization of Iberia (Keay 1998). The export of olive oil formed the basis for the prosperity of many of the cities in this area throughout the period of the Roman Empire. In the same way, the rich fish stock in the Straits of Gibraltar, particularly tuna, was exploited by several coastal manufactories (cetariae) dedicated to salted fish (salsamenta) and fish sauce (garum et liquamen) (Lagóstena 1996a; 1996b; 2001; Lagóstena et al. 2007). Both products were subsequently distributed all over the Roman Empire, including the north-western frontier in Germania and Britannia (Remesal 1986; 1998a; Carrerras 2000; Remesal 2002; Étienne and Mayet 2002; Ehmig 2003). Besides the numerous shipwrecks from this period, the large dump at the capital in Rome (the so-called Monte Testaccio) has given a vivid impression of the large number of ceramic containers (amphorae)

1 The expression was created by Tarradell, although it was Ponsich who developed it, taking into account geopolitical factors: Tarradell 1959; 1960, 61; 1967; Ponsich 1970, 20; 1975; Remesal 1983; Ponsich 1991b; 1993; Chaves et al. 1998; Pons 2000, 1251-3; Niveau de Villedary 2001; Arévalo et al. 2004. 
used for the transport of olive oil. Amphora stamps and graffiti (tituli picti) offer an interesting field for studying the details of this ancient trade. For this reason, there has been a growing preoccupation with the analysis of these phenomena in recent years, dominated by ancient historians, epigraphists and pottery analysts (Harris 1993; Blázquez et al. 1994; Blázquez and Remesal 1999; 2001; 2003; Remesal 2004). At the same time, interdisciplinarity in fields like chemistry or mineralogy has created new tools, especially for questions relating to the origin and distribution of the amphorae (Di Filippo et al. 1996; 1999; Grubessi 1999; Grubessi and Conti 1999; Conti et al. 1999; Ehmig 2003; Congreso 2001).

In the case of the olive oil trade from southern Spain, raw data are provided on the one hand by the amphorae found at the receiving end, as at Monte Testaccio in Rome and the frontier zone in the north-west, while on the other hand, the analysis of the distribution of the amphora stamps themselves in the area of origin has revealed significant information about the organization, localization and structure of the figlinae and their system of commercialization (Remesal 1977/78; 1980; 1989; Remesal et al. 1997; Pons and Berni 2002; Bernal and Lagóstena 2004). In contrast, there is a lack of detailed information for identifying the complex installations necessary in the production of oil, not only the various kilns used for the manufacturing of the amphorae, but also the oil presses and mills themselves. For example, there are numerous indications of olive presses or elements throughout the entire Baetis Valley (Ponsich 1974; 1979; 1987; 1991a; Remesal 1998b; Serrano 2005), but the largest excavated pars rustica dedicated to olive oil production is located, interestingly, in the neighbouring province of Lusitania. In an area in which we have, at the moment, no evidence for the production of the typical olive oil amphora Dressel 20, recent excavations at the Roman villa at Milreu (Estói) have brought to light a large olive oil production complex, consisting of five presses arranged in a line and storage rooms with a large quantity of dolia (Neville and Teichner 2000; Teichner 2001; 2002; 2004; 2005; 2008).

In the case of garum production in the south of Iberia, the situation seems to be reversed. The epigraphic sources, especially the information provided by amphora stamps, are poorer, but a large number of production vats have been excavated all around the coast of Iberia. These characteristic fish-salting tanks, lined with opus signinum and always located near the sea, are a clear indication of the production of salted fish and garum in antiquity (Lagóstena et al. 2007). At the same time, we have much information about the typical amphorae used for these fish products. One of the best known regions for this ancient coastal economy includes the river estuaries of the Tejo and Sado near Lisbon. Intensive research by Portuguese and French archaeologists has shown, in this micro-region, a complex interaction between amphora potters and fish sauce producers in the same centres, such as Caetobriga (Setubal), Troia and Felicitas Iulia Olisipo (Lisbon) itself. ${ }^{2}$ But surprisingly enough, while we have an enormous number of fish salting and fish sauce production sites along the entire Lusitanian coastline (including the Algarve coast), the typical Lusitanian fish sauce amphora, the Almagro 50 and 51a-c, seems to be under-represented east of the columns of Heracles (Fabião 2004). The amount of Lusitanian amphorae in the commercial area of the mare nostrum and the neighbouring provinces is so small that Spanish researchers have recently considered the possibility that other containers were filled

2 Étienne, Makaroun and Mayet 1994; Mayet, Schmitt and Tavares da Silva 1996; Mayet and Tavares da Silva 1998; 2002. Comp. for the purple-production in Lusitania: Teichner 2006; 2007; 2008. 
with Lusitanian products before reaching the Mediterranean, probably at Gades (Cadiz), the most important harbour of Baetica (Lagóstena et al. 2007).

This brings us directly back to the economic region of the Straits of Gibraltar: the importance and predominance of Baetican producers and traders in the region is a central trend in the current interpretation of the Roman economy. The exports from the Roman province south of the Straits, Mauretania Tingitana, are seen merely as a continuation of the Baetican economy.

Thanks to intensive French research carried out in Morocco and Algeria, some of the largest installations for fish sauce production from the Roman imperial period are known in this area. Sites like Cotta and Lixus and their architecture are synonyms for fishing and the manufacturing of salsamenta and garum. ${ }^{3}$ But, surprisingly enough, we have little information about the production of the necessary containers, the amphorae, in Mauretania Tingitana. Certainly, some tituli picti on amphorae such as CO(r)D(ula) LIX(itana) VE(tus) or CO(r)D(ula) TING(itana) VET(us) prove their African origin (CIL IV, 5629, 5630, 5631, 5632, 5636, 5637; Liou 1987, 66-9; Martín-Kilcher 1994, 404 p. 27; Étienne and Mayet 1998, 39-40; Martínez Maganto 2001). The lack of kilns producing these amphorae in the area is the starting point for the creation of a theory concerning the ancient economy of Baetica and Tingitana: it has been postulated in the last decade by Spanish researchers that Baetica provided containers of fish sauce to Tingitana. The syllogism of this hypothesis is based on the following premises. First: Tingitana was a great producer of fish sauce but not of amphorae in which to transport these liquids. Secondly: Baetica was a producer both of fish sauce and of fish sauce containers. Conclusion: the fish sauce from Tingitana was packed in Baetican containers. This argument has logic, but it may not relate to the historical truth, given that it has been built upon partial data, and excessive emphasis on the predominance of Gades and the omnipresence of the economic influence of the 'Circle of the Straits'.

The first to suggest this hypothesis was M. Ponsich (1975, 672, 677). In his view, Gades controlled fishing and garum production, both on the European and African shores of the Straits, so it was natural that it should impose the use of Baetican fish sauce containers. This would mean the substitution of the Baetican Dressel 7-11 amphora for the autochthonous Mañá C2 amphora. ${ }^{4}$ The containers would have been produced in Gades and transported empty to Tingitana, filled with Tingitanian fish sauce and returned to Gades, from where they were exported to the entire western Mediterranean as a product of Gaditan origin. ${ }^{5}$

The idea has been maintained until very recently, contrary to archaeological fact, that no kilns capable of producing the fish sauce amphorae have been found in Tingitana. ${ }^{6}$ But the idea that empty amphorae were transported seems to be, as one of the authors described it, one of 'severe irrationality' (Pons 2000, 1260-1; 2002/3, 392). On the one hand, it was completely uneconomic to produce the containers for goods on the European shore of the Straits and to produce the goods themselves on the African shore, because the amphorae were extremely cheap and easy to manufacture. On the other hand, in Tingitana, several firing failures of a variety of fish sauce vessels from the Republican period and the early Empire were already known, which

3 Cotta: Ponsich and Tarradell 1965, 55-68; Ponsich 1988, 150-9. Lixus: Ponsich and Tarradell 1965, 93-7; Ponsich 1988, 103-36.

4 This process was initiated in the Bay of Cádiz, cf. Lagóstena 1996a; 1996b, 151-3; 2001, 277-8.

5 Strab. 2; 3. 1; 4; Ponsich 1975, 672, 677 with bibliography; Étienne and Mayet 1998.

6 Villaverde 1992, 334-7; Villaverde and López Pardo 1995; Bravo et al. 1995; Villaverde 2001; Bernal and Pérez 2001, 876-8; Gozalbes 2001; 2002, 133-5. Cf. Pons 2007 for details on each author's hypothesis. 
hinted at the possibility of the appearance of later kilns. ${ }^{7}$ One should, therefore, have expected to find kilns dedicated to the production of fish sauce amphorae in the early Empire in Morocco (Pons 2000, 1260-1). In fact, this happened in 2000, when an Italian-Moroccan mission found and excavated kilns at Thamusida (Sidi Ali ben Ahmed, Morocco) that produced amphorae from the Dressel 7-11 and Beltran IIB types. ${ }^{8}$

Even if these recent results, when fully published, lead to a correction of the existing models of the economy of the 'circle of the Straits', it is worthwhile checking the reasons for the existing asymmetrical distribution of archaeological data on both shores. Looking carefully at the history of scientific fieldwork in the area during the twentieth century, it is possible to find reasons for the 'lack of kilns' in Tingitana.

It is an open secret that archaeological investigation is always strongly influenced by the historical context, namely the availability of financial support, cultural legislation and public attention. In Roman times, the sea between Africa and Europe was merely an internal boundary separating two provinces of the same Empire. But after the final triumph of Catholic Spain, the conquest of Granada in 1492, the situation changed. Gibraltar, the Gabel-al-Tarik, marks in modern times a frontier between two cultural, religious and economic systems.

As regards the history of archaeological investigation in Mauritania Tingitana, we must be aware that most of our knowledge dates back to the French and Spanish presence in North Africa. All the famous fish sauce production centres mentioned above - such as Lixus and Cotta - were excavated in the 1950s and 1960s by 'European' scholars such as M. Ponsich and M. Tarradell. Thanks to their intensive fieldwork we are familiar with the impressive architecture of these production buildings (cetariae). But in the bibliography of that time, systematic analyses of small finds were restricted to oil-lamps as part of the art-historically-influenced typological studies of fine wares, ${ }^{9}$ while coarse wares or amphorae were only very rarely studied.

Unsurprisingly, the major changes in political systems in North Africa in the middle of the twentieth century had a specific impact on archaeological investigation in this region. After the independence of Morocco in 1956 and Algeria in 1962, the situation became more difficult for archaeologists from Europe. Most of the fieldwork projects in this area stopped. Scholars who had previously been in charge of investigations in Roman North Africa 'migrated' to the Iberian Peninsula. Many important projects relating to the archaeology of Hispania Romana, for example the excavations at Baelo Claudia (Spain) or at Conimbriga (Portugal), as well as the important survey work done in the Baetis Valley and in the Sado and Tejo region, were initiated as a result. ${ }^{10}$

7 Mañá A and B: Banasa (Arharbi and Lenoir 1998). Mañá C2b: Kouass (a synthesis in Aranegui et al. 2004, 366-7); Banasa (Arharbi et al. 2001; Arharbi and Lenoir 2004; Aranegui et al. 2004, 364-5); Volubilis (Majdoub 1996, 297-300); Sala (Boube 1987/88 [1994], 191-2 n. 66). Dressel 7/11: Tamuda (Majdoub 1994, 302); Zilil (Pons 2000, 1261); Lixus (Izquierdo et al. 2001, 160-1; Bonet et al. 2005, 127); Sala (Boube 1987/88, 193; Arharbi and Naji 2004, 183 n. 61); Volubilis (Behel 1993, 343-7 apud Arharbi and Naji 2004, 183 n. 59). Sala I/Lomba do Canho: Sala (Boube 1973/75, 227-30; 1979/80; 1987/88, 186-8; Boube 1999, 67). Dressel 9?/Dressel 10?: Ä̈n Mesbah (Pons 2002/3, 392 n. 1; Bonet et al. 2005, 122 n. 7; Arharbi and Naji 2004, 187; Aranegui et al. 2004, 368; Pons 2007). Haltern 70?: Ä̈n Mesbah (idem); Sala (Boube 1973/75, 227 nos. 113-14).

8 Pons 2007; 2008; Laura Cerri's paper in the same Proceedings and http://www.archeo.unisi.it/ Archeologia_classica/province_romane/thamusida/fornaci.html.

9 For example: Ponsich 1961; Deneauve 1969.

10 Baelo: Sillières 1995. Conimbriga: Itineraires 1997. Baetica: Ponsich 1974; 1979; 1987; 1991a. Sado/Tejo region: Étienne, Makaroun and Mayet 1994; Étienne and Mayet 2002. 


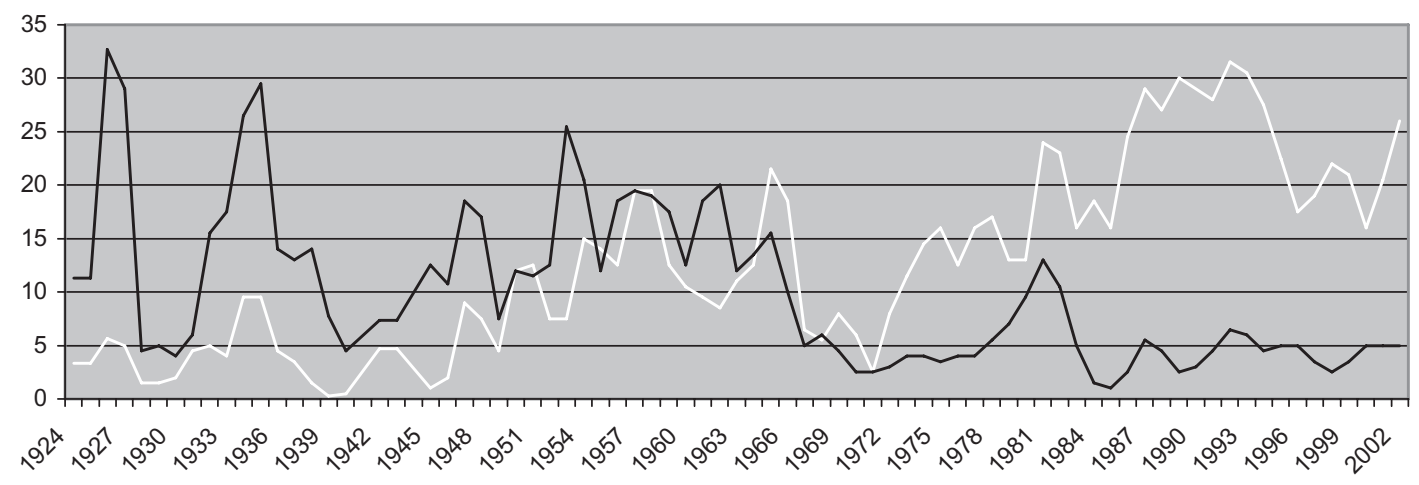

Figure 1

The graph shows the absolute number of publications dedicated to the Roman archaeology and history of the Iberian Peninsula (Portugal and Spain: white line) and the opposing side of the Straits (Morocco, Algeria, Mauritania and Tunisia: black line) between 1924 and 2002 (source: 1924-1976 Année Philologique; 1976-1993 Archäologische Bibliographie (DAI); 1994-2003 Dyabola (DAI)).

Progress in archaeological methodology meant that this fieldwork was no longer dedicated only to architecture and 'les beaux-arts'. Systematic investigation of the cetariae inside a Roman city centre (in the case of Baelo) was combined with the investigation of the typology of the amphorae and the pottery kilns in the hinterland in order to gain a wider picture of the Roman economy in a certain region ('micro-economy'). These new directions in the archaeology of the 1970s were adopted by the national archaeology of post-Franco Spain and post-Salazar Portugal, with important results. ${ }^{11}$ The improvement of cultural heritage legislation, the installation of local archaeologists and new regional universities led to a boom in archaeology. In the case of Baetica it is not just the intensive investigation of Phoenician, Punic and Roman economic activity - especially amphora production - in the Bay of Cadiz that impresses. For example, during the 1980s and 1990s it was possible to identify numerous pottery workshops, the figlinae for coarse ware and amphorae, throughout the entire province of Baetica (Bernal and Lagóstena 2004).

But on the opposite side of the Straits of Gibraltar, archaeological fieldwork failed to progress at the same rate. On the basis of the recorded bibliographies in the Année Philologique and the Archäologische Bibliographie of the Deutsches Archäologisches Institut, referring to Spain and Portugal on the one hand (Fig. 1, white line) and to Morocco, Algeria, Mauritania and Tunisia on the other hand (Fig. 1, black line), a simple graph shows the evolution of Roman archaeology in both regions. In particular, the data in the Année Philologique, founded in Paris by the Latinist Jules Marouzeau (1878-1964), indicate the significance of French archaeological investigation in North Africa in the first half of the twentieth century. In contrast, at the same time, publications referring to Hispania Romana were few. World War II, with all the struggles in North Africa, does not seem to have had a large impact on investigations in the area. Only the

11 For Portugal: C. Fabião, Archaeology and nationalism: the Portuguese case. In Díaz and Champion 1996, 90-107. For Spain: Díaz 1993; 1997; Gozalbes 2003; M. Díaz-Andreu, Islamic archaeology and the origin of the Spanish nation. In Díaz and Champion 1996, 68-89. 
end of the French and Spanish presence in Algeria and Morocco marked a turning point for Roman archaeology in these countries, now often referred as 'pre-Islamic archaeology'. Simultaneously, the number of publications on Roman Hispania increased significantly during the 1970s, reaching a peak during the new democratic systems of the 1980s and 1990s (Wulff and Álvarez 2003).

Returning to the problem of the apparent lack of amphora production in Mauretania Tingitana, the graph offers a simple explanation. In the second half of the last century, at the time when Islamic archaeology in North Africa was gaining importance at the expense of Roman archaeology, in Spain and Portugal progress continued to be made. North of the Straits, archaeologists no longer dedicated their time only to the discovery of fine arts and main architectural buildings, but also paid the same amount of attention to small finds and landscape archaeology, important for modelling the complex ancient reality and economy. In particular, new methods and techniques of fieldwork and excavation facilitated progress in identifying, for example, the large number of Roman pottery kilns and figlinae.

It seems, therefore, more likely that the lack of amphora kilns in Tingitana is a reflection of the evolution of European archaeological investigation in the twentieth century, rather than a representative image of the ancient reality. Hence, we have to consider that the current state of investigation does not allow us to postulate the transport of Roman amphorae from southern Baetica, especially from the economically important area of Gades (Cadiz) and the surrounding villages such as Puerto Real and Puerto de Santa María, to northern Africa. As Y. Garlan puts it '( . . . ) comme [the amphorae]... ne valaient pas tant par elles mêmes que par leur contenu et que leur fabrication ne devait généralement pas poser de problème, elles avaient en effet peu de chances d'être transportées vides sur de longues distances, à partir de leur lieu d'origine', (Garlan 1983, 37).

Special caution should be exercised in the case of every conclusion 'ex silentio'. For example, the similar transport of empty amphorae has also been suggested for other regions of the ancient world: the shipping of empty amphorae from Rhodes to Alexandria or sites on the Black Sea has been raised as a feasible response to the poor quality of clay in the receiving centres. ${ }^{12} \mathrm{R}$. Étienne considers that the wine produced on the island of Mallorca during the first century BC could have been exported in amphorae from the nearby kilns of the island of Ebusus (Ibiza) (Étienne 1982, 11-12). And more recently, D. Bernal has proposed the hypothesis for the city of Baelo Claudia, a great producer of fish sauce where amphora kilns are not known, that its amphorae were supplied by sea from El Rinconcillo (Algeciras, Cádiz). He also proposes that various cetariae in the suburbs of Almuñecar would have had their containers supplied by the workshop of Los Matagallares (Salobrena, Granada). Based upon these two examples, he offers the theory of centralized figlinae provided with optimal conditions for ceramic production (water, clay and wood), placed near the coastline in order to export containers by sea. Perhaps this explains - as a consequence of his working hypothesis - the concentration of workshops in the Bay of Cadiz and in the mouths of the Tejo and Sado (Bernal 1999).

12 Sherwin-White 1978, 241; Sadurska 1961, 110. Contra Garlan 1983, 43 n. 2, 'Il me parai invraisembable que Rhodes, par exemple, ait abondamment exporté des amphores vides à Alexandrie ou en Mer Noire, comme l'imaginent (. . .) Même dans les grands centres importateurs devait normalement exister une production locale d'amphores - à laquelle on ne s'est guère intéressé et qui reste le plus souvent difficile à identifier. Cela ne veut cependant pas dire, comme on le verra ci-dessous, qu'il n'ait pas existé de marchés locaux d'amphores vides, neues ou de récuperation'. 
It has been shown above that, in the case of Mauritania Tingitana, modern-day factors, caused in this particular case by post-colonialism, could be the reason for the asymmetrical distribution of archaeological data and information. Hence, conclusions drawn from this may be biased and do not necessarily reflect the ancient reality. As in any other discipline, landscape archaeology and its distribution maps need to pay attention to methodological problems, otherwise raw data are liable to be quarried in search of arguments to prove pre-existing theories.

\section{Acknowledgements}

We wish to thank Professor Jean Andreau (EHESS, Paris), Professor Andrew Wilson (Oxford) and Professor José Remesal Rodriguez (CEIPAC, Barcelona) for their kind suggestions.

(FT) Institut für Archäologische Wissenschaften II Archäologie und Geschichte der römischen Provinzen sowie Hilfswissenschaften der Altertumskunde Johann-Wolfgang-Goethe-Universität Grüneburgplatz 1 60323 Frankfurt am Main GERMANY e-mail: teichner@em.uni-frankfurt.de (LPP) Universidad de Cádiz Seminario Agustin de Horozco E-11002 Cadiz SPAIN

e-mail: luis.pons@uca.es

\section{REFERENCES}

ANDREAU, J. 2005: La modernité du domaine d'Appianus. Topoi (Paris) 12, 304-9.

ANDREAU, J. and maUCOURANT, J. 1999: A propos de la 'rationalité économique' dans l'Antiquité grécoromaine. Une interprétation des thèses de Dominic Rathbone (1991). Topoi (Paris) 9, 47-102.

ARANEgUi GaSCó, C., KBIRI AlAOUI, M. and VIVES-FERRÁNDIZ SÁNCHEZ, J. 2004: Alfares y producciones cerámicas en Mauritania Occidental. In Bernal and Lagóstena 2004, 363-78.

ARÉVAlo GONZÁlez, A., Bernal CASASOla, D. and TORREMocha Silva, A. (eds.) 2004: Algeciras. Garum y salazones en el Círculo del Estrecho. Fundación Municipal de Cultura José Luis Cano, MayoSeptiembre 2004 (Algeciras).

ARHARBI, R. and LENOIR, É. 1998: Banasa préromaine: novelles découvertes, mai 1997. Nouvelles Archéologiques et Patrimoniales 2, 8.

ARHARBI, R. and LENOIR, É. 2004: Les niveaux préromains de Banasa. Bulletin d'Archéologie Marocaine 20, 220-70.

ARHARBI, R., LENOIR, É. and KERMORVANT, A. 2001: Iulia Valentia Banasa: de la découverte du site aux recherches récentes. In Plus d'un siècle de recherches archéologiques au Maroc. Actes de Ieres Journées Internationales d'Archéologie et du Patrimoine 2 (Rabat), 147-68.

ARHARBI, R. and NAJI, H. 2004: Les amphores de Khedis à l'époque maurétanienne. In Zevi, G. and Turchetti, R., Méditerranée Occidentale antique: les échanges (Soveria Mannelli), 169-88. 
BEHEL, M. 1993: Le versant Est de la ville ancienne de Volúbilis (Paris).

BERnAl CASASOlA, D. 1999: Transporte de envases vacíos en época romana: a propósito de dos talleres anfóricos béticos de época alto (El Rinconcillo, Algeciras, Cádiz) y bajo imperial (Los Matagallares, Salobreña, Granada). In II Congreso de Arqueología Peninsular, Zamora 19964 (Zamora), 359-61.

Bernal CaSASOla, D. and lagóstena barrios, L. (eds.) 2004: Figlinae baeticae: talleres alfareros y producciones cerámicas en la Bética romana (ss. II a.C.-VII d.C.): Actas del Congreso Internacional (Oxford, BAR Int. Ser. 1266).

Bernal CaSASOla, D. and PÉRez Rivera, J.M. 2001: Las ánforas de Septem Frates en los ss. II y III d.C. Un modelo de suministro de envases gaditanos a las factorías de salazones de la costa tingitana. In Congreso 2001, 861-87.

BLÁzquez martínez, J.M. and REMESAl RodríGUeZ, J. (eds.) 1999: Estudios sobre el Monte Testaccio (Roma) I. Corpus International des Timbres Amphoriques 7 (Barcelona, Instrumenta 6).

BLÁzQUez MARTínez, J.M. and REMESAL RODRÍGUeZ, J. (eds.) 2001: Estudios sobre el Monte Testaccio (Roma) II. Corpus International des Timbres Amphoriques 8 (Barcelona, Instrumenta 10).

BLÁzquez MARTíNez, J.M. and REMESAL RODRÍGUez, J. (eds.) 2003: Estudios sobre el Monte Testaccio (Roma) III. Corpus International des Timbres Amphoriques 9 (Barcelona, Instrumenta 14).

BLÁZQUEZ MARTíNeZ, J.M., REMESAL RODRÍGUEZ, J. and RODRÍGUEZ ALMEIDA, E. 1994: Excavaciones arqueológicas en el Monte Testaccio (Roma). Memoria de la campaña 1989 (Madrid).

BONET ROSADO, H., VIVES-FERRÁNDIZ SÁNCHEZ, J., JHIRI ALAOUI, M. and HASSINI, H. 2005: La ocupación púnico mauritania. In Aranegui Gascó, C. (ed.), Memoria de las excavaciones arqueológicas realizadas en la ladera sur de Lixus (Larache) por el equipo marroco-español entre 2000 y 2003 (Valencia, Saguntum Extra 6), 87-140.

Boube, J. 1973/75: Marques d'ámphores découvertes à Sala, Volubilis et Banasa. Bulletin d'Archéologie Marocaine 9, 163-235.

Boube, J. 1979/80: Amphores préromaines trouvées en mer au voisinage de Rabat. Bulletin d'Archéologie Marocaine 12, 99-109.

BOUBE, J. 1987/88: Les amphores de Sala à l'époque Mauretanienne. Bulletin d'Archéologie Marocaine 17, 183-207.

Boube, J. 1999: Les nécropoles de Sala (Paris).

BRAVO PÉReZ, J., MARFIL RUIZ, P., VILladA PAREDES, F. and hita RUIZ, J.M. 1995: Nuevos datos sobre la economía del territorio ceutí en época romana: las factorías de salazón. In II Congreso Internacional "El Estrecho de Gibraltar" - Ceuta 19901 (Madrid), 439-54.

CARRERAS MONFORT, C. 2000: Economía de la Britannia romana: la importación de alimentos (Barcelona, Instrumenta 8).

CARRIÉ, J.-M. 2005: Une rationalité quand même? Topoi (Paris) 12-13, 293-303.

CHAVES TRISTÁN, F., GARCía VARGAS, E. and FERRER ALbelda, E. 1998: Datos relativos a la pervivencia del denominado "Círculo del Estrecho" en época republicana. In L’Africa romana XII 3 (Sassari), 130720.

CHRISTENSEN, P. 2003: Economic rationalism in fourth century BC Athens. Greece and Rome 50, 3156.

CONGReso 2001: Congreso Internacional Ex Baetica Amphorae. Conservas, aceite y vino de la Bética en el Imperio Romano. Sevilla-Écija, 17-20 de diciembre de 1998 (Écija).

CONTI, L., BURRaGato, F. and GRUBESSI, O. 1999: Le anfore nordafricane del Monte Testaccio. In Blázquez and Remesal 1999, 473-512.

DENEAuve, J. 1969: Lampes de Carthage (Paris). 
DI FILIPPO, M., GRUBESSI, O. and TORO, в. 1996: Un essempio di applicazione del metodo gravimetrico nell' area archeologica del Monte Testaccio (Roma). In Actes du colloque de Périgueux 1995 (Supplément à la Revue d'Archéométrie), 31-6.

DI FILIPPO, M., GRUBESSI, O. and TORO, B. 1999: Progetto Testaccio. Indagine gravimetrica nell'area archeologica del Monte Testaccio (Roma). In Blázquez and Remesal 1999, 445-52.

DíAZ-ANDREU, M. 1993: Theory and ideology in archaeology. Spanish archaeology under the Franco regime. Antiquity 67, 74-82.

DÍAZ-ANDREU, M. 1997: Prehistoria y Franquismo. In Mora, G. and Díaz-Andreu, M., La cristalización del pasado: génesis y desarrollo del marco institucional de la arqueología en España (Málaga), 547-52.

DíAZ-ANDREU, M. and CHAMPION, T. 1996: Nationalism and archaeology in Europe (London).

EHMIG, U. 2003: Die römische Amphoren aus Mainz (Möhnesee).

ÉTIENNE, R. 1982: Le vin des Baléars. In Majorque, Languedoc et Roussillon de l'Antiquité à nos jours (Montpellier), 5-12.

Étienne, R., MAKARoun, Y. and MAYet, F. 1994: Un grand complexe industriel à Tróia (Portugal) (Paris). ÉTIENNE, R. and MAYET, F. 1998: Les mercatores de saumure hispanique. Mélanges de l'École Française à Rome 110, 147-65.

ÉtIENNe, R. and MAYET, F. 2002: Salaisons et sauces de poisson hispaniques (Paris).

FABIÃO, C. 2004: Centros oleiros de Lusitânia. Balanço de conhecimentos e perspectivas de investigação. In Bernal and Lagóstena 2004, 349-410.

GARLAN, Y. 1983: Le commerce des amphores grecques. In Garnsey, P. and Whittaker, C.R. (eds.), Trade and Famine in Classical Antiquity (Cambridge), 37-44.

GOZALBES CRAVIOTO, E. 2001: Las ánforas béticas en Mauritana Tingitana ¿importación o exportación? In Congreso 2001, 887-99.

GOZALBES CRAVIOTO, E. 2002: Notas sobre las relaciones hispano-tingitanas en la antigüedad clásica. In Vivre, produire et échanger: reflets méditerranéens. Mélanges offerts à Bernard Liou (Montagnac), 133-9.

GOZALBES CRAVIOTO, E. 2003: África Antigua en la historiografía y arqueología de época franquista. In Wulff and Álvarez 2003, 135-60.

GRUBeSSI, O. 1999: Progetto Testaccio, Roma. Uno studio archeometrico delle anfore Dressel 20. In Blázquez and Remesal 1999, 365-424.

GRUBESSI, O. and CONTI, L. 1999: Progetto Testaccio. Studio archeometico delle anfore Dressel 20: nota II. Confronto analitico tra reperti spagnoli Tejarillo e La Catria e M. Testaccio. In Blázquez and Remesal 1999, 513-42.

HARris, W.v. (ed.) 1993: The inscribed economy. Production and distribution in the Roman Empire in the light of "instrumentum domesticum" (Ann Arbor, Journal of Roman Archaeology Suppl. 6).

ITINERAIRES 1997: Itinéraires lusitaniens. Trente années de collaboration archéologique luso-française (Paris).

IZQUIERDO PERAILE, M.I., MILOU, B. and BONET ROSADO, H. 2001: Las fases púnico-mauritanas I (175/150 a 80/50 a.C.) y II (80/50 a.C.-15 d.C.). In Aranegui Gascó, C. (ed.), Lixus, colonia fenicia y ciudad púnico-mauritana. Anotaciones sobre su ocupación medieval (Valencia, Saguntum Extra 4), 141-68.

KEAY, s. 1998: The Archaeology of early Roman Baetica (Portsmouth, Journal of Roman Archaeology Suppl. 29).

Lagóstena barrios, L. 1996a: Alfarería romana en la Bahía de Cádiz (Cádiz).

LAGóstena BARrios, L. 1996b: Explotación del salazón en la Bahía de Cádiz en la Antigüedad: aportación al conocimiento de su evolución a través de la producción de las ánforas Mañá C. Florentia Iliberritana 7 , 141-69. 
LAGÓSTENA BARRIOS, L. 2001: La producción de salas y conservas de pescado en la Hispania Romana (II a.C.-VI d.C.) (Barcelona, Instrumenta 11).

LAGÓSTENA BARRIOS, L., BERNAL CASASOlA, D. and ARÉVALO GONZÁLEZ, A. (eds.) 2007: Cetariae 2005. Salsas y Salazones de Pescado en Occidente durante la Antigüedad. Actas del Congreso Internacional (Cádiz, 7-9 de noviembre de 2005) (Oxford, BAR Int. Ser. 1686).

LAUtman, J. 2005: Entre magie et comptabilité. Topoi (Paris) 12-13, 311-14.

LIOU, B. 1987: Inscriptions peintes sur amphores: Fos (suite), Marseille, Toulon, Port-La-Nautique, Arles, Saint-Blaise, Saint-Martin-De-Crau, Mâcon, Calvi. Archaeonautica 7, 55- 139.

Lo Cascio, E. and RATHBone, D.w. (eds.) 2000: Production and public powers in classical antiquity (Cambridge).

Majdoub, M. 1994: Nouvelles données sur la datation du temple C à Volubilis. In L'Africa romana X 1 (Sassari), 283-7.

MAJdOub, M. 1996: La Maurétanie et ses relations commerciales avec le monde romain jusqu'au Ier s.av. J.-C. In L'Africa romana XI 1 (Sassari), 287-302.

MARTín-KILCHER, S. 1994: Die römischen Amphoren aus Augst und Kaiseraugst. Ein Beitrag zur römischen Handels- und Kulturgeschichte (Augst, Forschungen in Augst 7).

MARTíNEZ MAGANTO, J. 2001: Inscripciones sobre ánforas de salazón: interpretación sobre la estructura y significación comercial de los tituli picti. In Congreso 2001, 1207-19.

MAYet, F., SChmitt, A. and tavares Da Silva, c. 1996: Les amphores du Sado (Portugal). Prospection des fours et analyse du matériel (Paris).

MAYet, F. and TAVARES DA SILVA, C. 1998: L'Atelier d'amphores de Pinheiro (Portugal) (Paris).

MAYET, F. and TAVARES DA SILVA, C. 2002: L'atelier d'amphores d'Abul (Portugal) (Paris).

MINAUD, G. 2005: Rationalité modulable des comptabilités. Topoi (Paris) 12-13 , 271-81.

NEVILle, A. and TEICHNER, F. 2000: Christianization, Romanization and Islamization in Southern Lusitania. Antiquity 74(1), 33-4.

NIVEAU DE VILLEDARY Y MARIÑAS, A.M. 2001: El espacio geopolítico gaditano en época púnica. Revisión y puesta al día del concepto de "Círculo del Estrecho. Gerión 19, 313-54.

PONS PUjoL, L. 2000: La economía de la Mauretania Tingitana y su relación con la Baetica en el Alto Imperio. In L'Africa romana XIII 2 (Carocci), 1251-89.

PONS PUJOL, L. 2002/3: Reseña a Villaverde Vega, Noé: Tingitana en la Antigüedad Tardía (siglos III-VII). Autoctonía y romanidad en el extremo occidente mediterráneo. Pyrenae 33-4, 391-3.

PONS PUJOL, L. 2007: Contenedores para la exportación de las salazones tingitanas en el Alto Imperio. In Lagóstena et al. 2007, 453-61.

PONS PUjOL, L. 2008: L'importation de l'huile de Bétique en Tingitane et l'exportation des salaisons de Tingitane (Ier-IIIe siècle après J.-C.). Cahiers du Centre Glotz. 17, 61-77.

PONS PUJOL, L. and BERNI MILLET, P. 2002: La figlina Virginensis y la Mauretania Tingitana. In L'Africa romana XIV 2 (Sassari), 1541-70.

PONSICH, M. 1961: Les lampes romaines en terrè cuite de la Maurétanie Tingítane (Rabat, Publ. du Service des Antiquites du Maroc 15).

PONSICH, M. 1970: Recherches archéologiques à Tanger et dans sa region (Paris).

PONSICH, M. 1974: Implantation rurale antique sur le Bas-Guadalquivir I (Madrid).

PONSICH, M. 1975: Perennité des relations dans le circuit du Détroit de Gibraltar. In Aufstieg und Niedergang der römischen Welt II.3, 654-84.

PONSICH, M. 1979: Implantation rurale antique sur le Bas-Guadalquivir II (Paris).

PONSICH, M. 1987: Implantation rurale antique sur le Bas-Guadalquivir III (Madrid). 
PONSICH, M. 1988: Aceite de oliva y salazones de pescado. Factores geoeconómicos de Bética y Tingitania (Madrid).

PONSICH, M. 1991a: Implantation rurale antique sur le Bas-Guadalquivir IV (Madrid).

PONSICH, M. 1991b: Prospección arqueológica: metodología para la lectura de un paisaje en la Antigüedad. Almoraima 5, 15-29.

PONSICH, M. 1993: Le circuit du Détroit de Gibraltar dans l'Antiquité. In Homenatge a Miquel Tarradell (Barcelona), 49-62.

PONSICH, M. and TARRADELl, M. 1965: Garum et industries antiques de salaison dans la Mediterranée Occidentale (Paris).

RATHBONE, D.W. 1991: Economic rationalism and rural society in third-century AD Egypt. The Heroninos archive and the Appianus estate (Cambridge).

RAThbone, D.w. 2005: Economic rationalism and the Heroninos Archive. Topoi (Paris) 12-13, 261-9.

REMESAL RODRíGUEZ, J. 1977/78: La economía oleícola bética: nuevas formas de análisis. Archivo Español de Arqueología 50-1, 87-142.

REMESAL RODRíGUEZ, J. 1980: Reflejos económicos y sociales en la producción de ánforas olearias béticas. In Producción y comercio de aceite en la Antigüedad. I Congreso de Madrid (Madrid), 131-53.

REMesal rodríguez, J. 1983: Imagen y función de Iberia en el Mediterráneo Antiguo. In Atti del I Congresso Internazionale di Studi Fenici e Punici (Rome), 837-45.

REMESAL RODRÍGUEZ, J. 1986: La annona militaris y la exportación de aceite bético a Germania (Madrid).

REMESAL RODRÍGUEZ, J. 1989: Tres nuevos centros productores de ánforas Dressel 20 y 23. Los sellos de Lucius Fabius Cilo. Ariadna 6, 121-51.

REMESAL RODRÍGUEZ, J. 1998a: Heeresversorgung und die wirtschaftlichen Beziehungen zwischen der Baetica und Germanien. Materialien zu einem Corpus der in Deutschland veröffentlichten Stempel auf Amphoren der Form Dressel 20 (Stuttgart).

REMESAl RodríGUeZ, J. 1998b: Baetican olive oil and the Roman Economy. In Keay 1998, 183-99.

REMESAL RODRÍGUEZ, J. 2002: Baetica and Germania. Notes on the concept of "provincial interdependence" in the Roman Empire. In Erdkamp, P., The Roman Army and the Economy (Amsterdam), 293-308.

REMESAl RODRíGUEZ, J. (ed.) 2004: Epigrafía anfórica (Barcelona, Instrumenta 17).

REMESAL RODRÍGUEZ, J., CARRERAS MONFORT, C. and REVILla CALVO, v. 1997: Arva: prospecciones en un centro productor de ánforas Dressel 20 (Alcolea del Río, Sevilla). Pyrenae 28, 151-78.

SAdursKa, A. 1961: Timbres amphoriques de Mirmeki. In Irmscher, J. and Shelov, D.B., Griechische Städte und einheimische Völker der Schwarzmeergebietes (Berlin).

SCHEIDEL, W. and VON REDEN, s. 2002: The ancient economy (New York).

SERRANO PEÑA, J.L. 2005: La producción de aceite en Jaén en la Antigüedad: evidencias arqueológicas. In XII Simposium científico-técnico Expoliva 2005 (Jaén).

SHERwin-white, S.M. 1978: Ancient Cos. An historical study from the Dorian settlement to the imperial period (Göttingen).

SILlières, P. 1995: Baelo Claudia. Une cité romaine de Bétique (Madrid).

TARRADEll, M. 1959: El Estrecho de Gibraltar ¿Puente o frontera? (Sobre las relaciones post-neolíticas entre Marruecos y la Península Ibérica). Tamuda 7, 123-38.

tarradell, M. 1960: El Marruecos Púnico (Tetuán).

TARradell, M. 1967: Los fenicios en Occidente. Nuevas perspectivas. In Harden, D., Fenicios (Barcelona), 277-314.

TCHERniA, A. 2005. Quelle rationalité? Topoi (Paris) 12-13, 283-91. 
TEICHNER, F. 2001: Resultados preliminares das últimas escavações na parte rústica noroeste da Villa romana de Milreu. In Actas do Encontro de Arqueologia do Algarve 2001. Xelb 4 (Silves), 103-15.

TEICHNER, F. 2002: Uma nova interpretação da área 21, a partir da da planta elaborada por Sebastião Philippes Martins Estácio da Veiga, sobre a Villa romana de Milreu (Estoi, Algarve) - notícia preliminar. O Arqueologo Portugues 20, 187-98.

TEICHNER, F. 2004: Descrição breve dos vestígios arqueológicos identificados por baixo da Casa Rural de Milreu (Algarve). Estudos IPPAR 6, 157-61.

TEICHNER, F. 2005: Neue Forschungen zu den römischen Villen Lusitaniens. In Akten des Kollquiums Vesprem 2004. Balácai Közlemények 9 (Vesprem), 117-32.

TEICHNER, F. 2006: Cerro da Vila: paleoestuário, aglomeração secundária e centro de fabricação de recursos maritimos. In Actas do Simpósio Internacional em homenagem a Françoise Mayet. Setubal Arqueologia 13, 100-23.

TEICHNeR, F. 2007: Casais Velho (Cascais), Cerro da Vila (Quarteira) y Torreblanca del Sol (Fuengirola): ¿Centros de producción de garum o de tintes en época romana? In Lagóstena et al. 2007, 117-25.

TEICHNER, F. 2008: Zwischen Land und Meer - Entre tierra y mar. Studien zur Architektur und Wirtschaftsweise ländlicher Siedlungen im Süden der römischen Provinz Lusitanien (Stvdia Lvsitana 3 (MNAR)/Madrider Beitr. (DAI)).

villaverde vegA, N. 1992: Comercio marítimo y crisis del siglo III en el "Circulo del Estrecho": sus repercusiones en Mauritania Tingitana. In Afrique du Nord Antique et Medievale. Spectacles, vie portuaire, religions. Ve Colloque international sur l'Histoire et l'Archéologie de l'Afrique du Nord - 115e Congrés Nationale des Sociétés Savantes (Paris), 333-47.

VILlaverde Vega, N. 2001: Tingitana en la Antigüedad tardía (siglos III-VII). Autoctonía y romanidad en el extremo occidente mediterráneo (Madrid).

Villaverde vega, N. and lópez PARdo, F. 1995: Una nueva factoría de salazones en Septem Frates (Ceuta). El origen de la localidad y la problemática de la industria de salazones en el estrecho durante el Bajo Imperio. In II Congreso Internacional "El Estrecho de Gibraltar" (Madrid), 455-72.

WUlfF Alonso, F. and Álvarez martí-Aguilar, M. (eds.) 2003: Antigüedad y franquismo (Málaga). 